\title{
Miminipossum notioplanetes, a Miocene forest-dwelling phalangeridan (Marsupialia; Diprotodontia) from northern and central Australia
}

\author{
Michael Archer, Pippa Binfield, Suzanne J. Hand, Karen H. Black, \\ Phillip Creaser, Troy J. Myers, Anna K. Gillespie, Derrick A. Arena, \\ John Scanlon, Neville Pledge, and Jenni Thurmer
}

\begin{abstract}
Miminipossum notioplanetes represents a new Early/Middle Miocene family (Miminipossumidae) of phalangeridan possums recovered from the Two Trees Local Fauna from the Riversleigh World Heritage area in northwestern Queensland and the Kutjamarpu Local Fauna of the Tirari Desert in northern South Australia. Because of widespread convergence in key features of $P_{3}$ and $M_{1}$ among phalangeridan families, the interfamilial relationships of Miminipossumidae are uncertain. The age of the Kutjamarpu Local Fauna has been in doubt with estimates ranging from Late Oligocene to Middle Miocene. The new taxon raises to 15 the number of taxa in the Kutjamarpu Local Fauna that are shared with both Riversleigh's Faunal Zone B (Early Miocene) and Riversleigh's Faunal Zone C (Middle Miocene) assemblages. Although there is relatively little biocorrelative support for the estimate of a Late Oligocene age, doubt remains about whether the age is more likely to be Early or Middle Miocene. In terms of palaeoenvironmental implications, because both Riversleigh's Early and Middle Miocene assemblages have been concluded to have accumulated in temperate, wet, species-rich lowland forests, the same or similar Early/Middle Miocene palaeoenvironments may well have extended into central Australia at the time when the Kutjamarpu assemblage was accumulating.
\end{abstract}

Michael Archer. Palaeontology, Geobiology and Earth Archives Research Centre (PANGEA), School of Biological, Earth and Environmental Sciences, University of New South Wales, Sydney 2052, Australia; m.archer@unsw.edu.au

Pippa Binfield. Palaeontology, Geobiology and Earth Archives Research Centre (PANGEA), School of Biological, Earth and Environmental Sciences, University of New South Wales, Sydney 2052, Australia; pippa.binfield@outlook.com

http://zoobank.org/F2286DA9-B627-46E3-A12F-AEB719B904A8

Archer, Michael, Binfield, Pippa, Hand, Suzanne J., Black, Karen H., Creaser, Phillip, Myers, Troy J., Gillespie, Anna K., Arena, Derrick A., Scanlon, John, Pledge, Neville, and Thurmer, Jenni. 2018. Miminipossum notioplanetes, a Miocene forest-dwelling phalangeridan (Marsupialia; Diprotodontia) from northern and central Australia. Palaeontologia Electronica 21.1.2A: 1-11. https://doi.org/10.26879/757

palaeo-electronica.org/content/2018/2109-new-family-of-marsupials

Copyright: January 2018 Palaeontology Association.

This is an open access article distributed under the terms of Attribution-NonCommercial-ShareAlike 4.0 International (CC BY-NC-SA 4.0), which permits users to copy and redistribute the material in any medium or format, provided it is not used for commercial purposes and the original author and source are credited, with indications if any changes are made.

creativecommons.org/licenses/by-nc-sa/4.0/ 
Suzanne J. Hand. Palaeontology, Geobiology and Earth Archives Research Centre (PANGEA), School of Biological, Earth and Environmental Sciences, University of New South Wales, Sydney 2052, Australia; s.hand@unsw.edu.au

Karen H. Black. Palaeontology, Geobiology and Earth Archives Research Centre (PANGEA), School of Biological, Earth and Environmental Sciences, University of New South Wales, Sydney 2052, Australia; k.black@unsw.edu.au

Phillip Creaser. Palaeontology, Geobiology and Earth Archives Research Centre (PANGEA), School of Biological, Earth and Environmental Sciences, University of New South Wales, Sydney 2052, Australia; philcreaser@grapevine.com.au

Troy J. Myers. Palaeontology, Geobiology and Earth Archives Research Centre (PANGEA), School of Biological, Earth and Environmental Sciences, University of New South Wales, Sydney 2052, Australia; t.myers@unsw.edu.au

Anna K. Gillespie. Palaeontology, Geobiology and Earth Archives Research Centre (PANGEA), School of Biological, Earth and Environmental Sciences, University of New South Wales, Sydney 2052, Australia; a.gillespie@unsw.edu.au

Derrick A. Arena. Palaeontology, Geobiology and Earth Archives Research Centre (PANGEA), School of Biological, Earth and Environmental Sciences, University of New South Wales, Sydney 2052, Australia; r.arena@unsw.edu.au John Scanlon. Outback at Isa, Mount Isa, Queensland 4825, Australia; nanowana@gmail.com Neville Pledge. Palaeontology, South Australian Museum, North Terrace, Adelaide 5000, Australia; Neville.Pledge@samuseum.sa.gov.au Jenni Thurmer. Palaeontology, South Australian Museum, North Terrace, Adelaide 5000, Australia; jthurmer@senet.com.au

Keywords: Miminipossumidae; Miocene; Riversleigh; Kutjamarpu; new genus; new species

Submission: 22 January 2017 Acceptance: 4 January 2018

\section{INTRODUCTION}

Australia's Neogene record for mammals has been steadily improving (Black et al., 2012) but the majority of contemporaneous fossil species described are unique to specific regions of the continent. This has impeded biocorrelation as well as the ability to determine the geographic extent of palaeoenvironments spanning the early Miocene to Pliocene. However, evidence has been steadily accumulating (ibid) that demonstrates many genera and species overlap between the Miocene Kutjamarpu Local Fauna of northern South Australia and Miocene faunal assemblages of Riversleigh in northwestern Queensland (Figure 1). Currently documented overlaps among marsupials include: thylacoleonids (Wakaleo oldfieldi; Gillespie et al., 2014), diprotodontids (Neohelos tirarensis; Black, 1997; Black et al., 2013), phascolarctids (Litokoala kutjamarpensis; Black et al., 2014a, 2014b), vombatids (Rhizophascolonus crowcrofti; Brewer et al., 2008), possible potoroids (Wakiewakie lawsoni; Godthelp et al., 1989), other macropodoids (Ganawamaya acris, Ganguroo bilamina; TravouilIon et al., 2014), pseudocheirids (Marlu syke, M. kutjamarpensis, M. ampelos, Paljara tirarensae; Bassarova et al., 2001; Roberts et al., 2008, 2009), perameloids (Madju variae, Bulungu palara; Travouillon et al., 2013) and perhaps ektopodontids (Ektopodon sp. cf. E. serratus; Pledge et al., 1999). Until now, however, no species of any of the petaurid-like arboreal possum genera that are well represented at Riversleigh have been found in any of the central Australian faunas.

Collections made in 1998 by authors of this paper (Archer, Hand, Black, Creaser, Myers, Gillespie, Arena, Pledge, Thurmer) at the Leaf Locality on the eastern edge of Lake Ngapakaldi in the Tirari Desert (Figure 1) have produced additional previously unknown taxa from this assemblage, including the new possum described here. This distinctive genus of small phalangeridans, which is represented in the Early to Middle Miocene assemblages of Riversleigh (Brammall and Archer, 1999, as 'Riversleigh Petaurid'), has until now not been formally named. Although there may be more than one species present in the Riversleigh assemblages, attention has been focused here on the new taxon that appears to be shared between Riversleigh assemblages and the Kutja- 


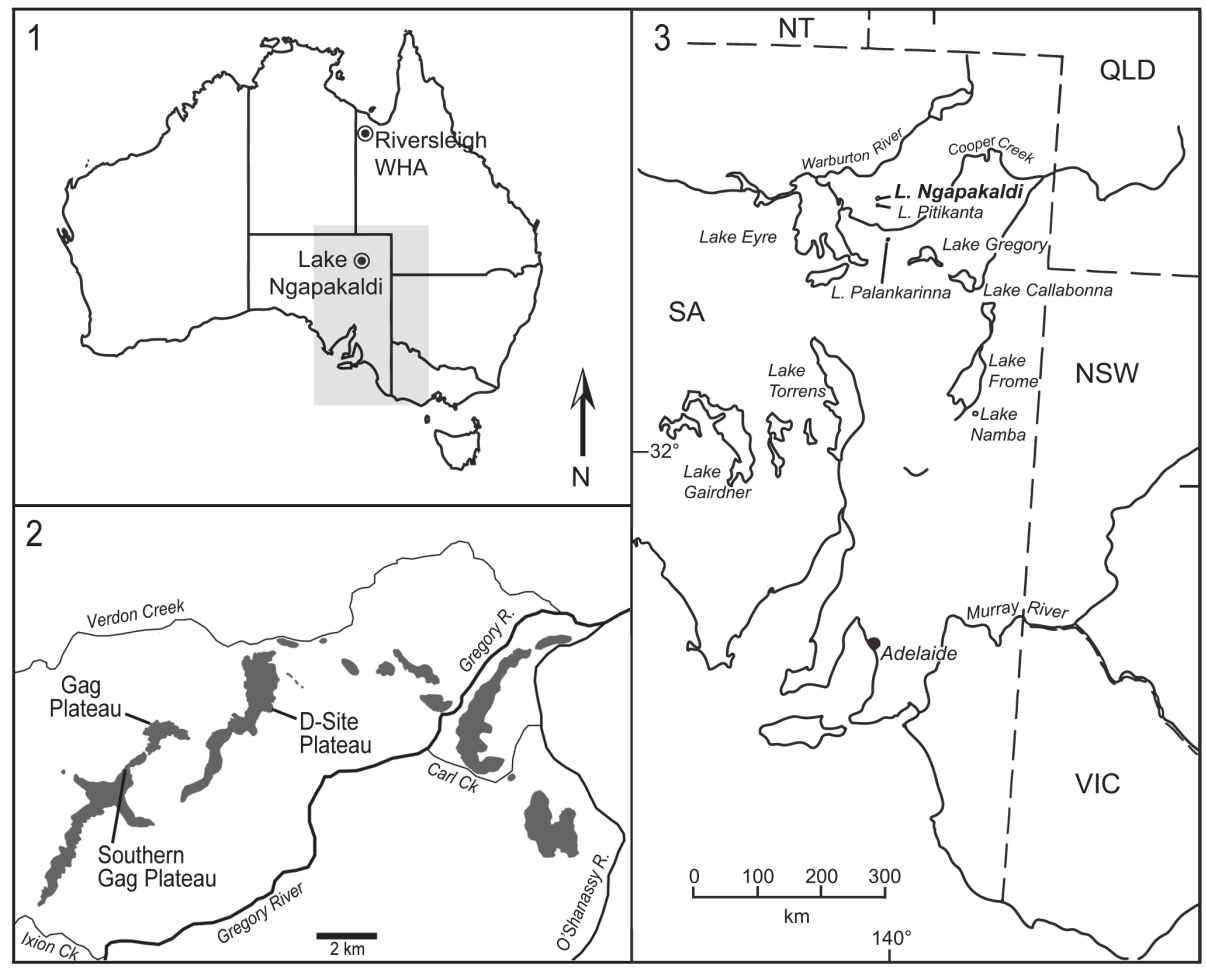

FIGURE 1. Fossil localities: 1, map of Australia showing the relative positions of the Two Trees Site at Riversleigh in Queensland, and the Leaf Locality in South Australia. 2, the Gag Plateau where the Two Trees Site occurs at Riversleigh. 3, Lake Ngapakaldi where the Leaf Locality occurs in South Australia. (Modified after: Woodburne and Tedford, 1975, figure 1; and Archer et al., 2016, figure 1).

marpu Local Fauna. This in turn enables refinement of understanding about the palaeoecology of this central Australian faunal assemblage and potentially further clarity about the otherwise uncertain age of the non-radiometrically-dated Kutjamarpu assemblage.

\section{MATERIALS AND METHODS}

Tooth position nomenclature used here for marsupials follows that used by all recent authors (e.g., Black et al., 2012) such that the only postcanine teeth involved in ontogenetic tooth replacement are dP3 and P3, and marsupials have four rather than five molars. Cusp and blade nomenclature follows that used by Archer (1984). Faunal Zone nomenclature for Riversleigh follows Arena et al. (2015). Local Fauna names follow Archer et al. (2006). Higher-level systematic nomenclature follows Aplin and Archer (1997). Matrix from Two Trees Site was collected in 2002 by M. Archer, S. Hand et al. (UNSW) and prepared by J. Scanlon at the Outback at Isa centre in Mount Isa. The Leaf Locality matrix was collected in 1998 by the authors of this paper, screen-washed in the Univer- sity of New South Wales and sorted in the South Australian Museum.

\section{Abbreviations}

Fm, Formation; LF, Local Fauna; QM F, catalogue number in the fossil collection of the Queensland Museum; SAM P, South Australian Museum Palaeontological collections.

\section{SYSTEMATIC PALAEONTOLOGY}

Order DIPROTODONTIA Owen, 1866

Suborder PHALANGERIDA Aplin and Archer, 1987

Family MIMINIPOSSUMIDAE nov.

zoobank.org/57A4795F-EA01-4FF6-8D13-8714CDFA0C95

Family diagnosis. Members of this family differ from those of all other phalangeridan families as follows. They differ from macropodids, balbarids, potoroids and hypsiprymnodontids in having bunodont rather than lophodont or hemilophodont molars. They differ from pseudocheirids in having bunodont rather than selenodont molars. They differ from burramyids in having a relatively elongate apical, multi-cuspid but not plagiaulacoid blade on $P_{3}$. They differ from phalangerids, pilkipildrids and 
miralinids in having a relatively simple $\mathrm{P}_{3}$ that is not hypertrophied or obliquely-orientated with respect to the long axis of the tooth row. They differ from acrobatids in having a simple $\mathrm{P}_{3}$ crown that lacks a hypertrophied arcuate piercing anterior cusp. They differ from tarsipedids in having well-developed rather than spicule-like cheekteeth. They differ from petaurids in having an enlarged $\mathrm{P}_{3}$ that reaches the height of the trigonid of $M_{1}$, in contrast to the reduced, low, button-like crown of all petaurids, and in having only three (not four) teeth between $I_{1}$ and $M_{1}$. They differ from the enigmatic petauroid Djaludjangi yadjana Brammall, 1998 in that $\mathrm{P}_{3}$ has two apical, approximated subequal cusps rather than one large anterior and one small posterior cusp.

Type and only known genus. Miminipossum gen. nov.

MIMINIPOSSUM gen. nov. zoobank.org/0A5D23A8-CCC0-4338-A23F-955BA188D154

Type species. Miminipossum notioplanetes sp. nov.

Etymology. The generic name involves a triple allusion: Mi refers to the Miocene time frame for this group of possums; mini refers to their diminutive size (as in minima); possum is the common name for arboreal phalangeridan marsupials in this and several other related families.

Gender. The genus Miminipossum is hereby given female gender.

Generic diagnosis. The diagnosis for the genus is that of the family Miminipossumidae until additional genera are known.

\section{Miminipossum notioplanetes sp. nov.}

(Figures 2-3)

\section{zoobank.org/0267FDE1-0BB9-48FD-BDD0-0C9E4A24BA98}

Holotype. QM F57950 is a right dentary fragment of a juvenile containing $I_{1}, P_{2-3}, M_{1}$, alveoli for $P_{1}$, $\mathrm{M}_{2-3}$ and an unerupted $\mathrm{M}_{4}$ that is still in the crypt (Figures 2.1-2.2, Figures 3.1-3.2). The dentary itself retains the entire alveolar region and anterior margin of the ascending ramus.

Type locality and local fauna. Two Trees Site, northeastern part of the Gag Plateau, Riversleigh World Heritage Area, northwestern Queensland (Figure 1). Precise coordinates for this locality may be obtained on request to the Queensland Museum. The faunal assemblage from this locality is the Two Trees Local Fauna.

Referred specimen and its context. SAM P49184 is a left dentary fragment that retains $P_{3}$,
$M_{1}$, the base of $I_{1}$, alveoli for $P_{1-2}$, alveoli for $M_{2}$ and part of the anterolingual corner of the alveolar margin for $\mathrm{M}_{3}$ (Figures 2.3-2.4, Figures 3.3-3.4). This specimen comes from the Basal Conglomerate Unit of the Wipajiri Formation (Campbell, 1976) exposed at the Leaf Locality on the eastern edge of Lake Ngapakaldi in the Tirari Desert of northern South Australia (Figure 1). The faunal assemblage from this locality is the Kutjamarpu LF (e.g., Sitrton et al., 1967; Campbell, 1976; Archer, 1984; Archer and Hand, 1984; Archer et al., 1999).

Age. The Two Trees LF at Riversleigh has been interpreted to be Middle Miocene in age (e.g., Flannery and Archer, 1987; Arena et al., 2015). Uranium/lead radiometric dates (Woodhead et al., 2014) for two other sites near the northeastern end of the Gag Plateau include Ringtail Site at $13.56 \pm$ $0.67 \mathrm{Ma}$ and D4 Site at $15.13 \pm 0.66 \mathrm{Ma}$ (Figure 1.2). The deposit at Two Trees Site has been interpreted as a cave deposit (e.g., containing speleothems) that formed within older Cenozoic fluviolacustrine carbonates (Arena, 2004; Arena et al., 2014). Arena et al. (2015) allocated the Two Trees LF to Riversleigh Faunal Zone C (i.e., Middle Miocene in age) because it contains Ganguroo robustiter (Cooke et al., 2015). One taxon from the Two Trees Site LF (Bettongia moyesi) also occurs (only) in the Henk's Hollow LF, which is also regarded by Arena et al. (2015) to be in Faunal Zone C. The age of the Kutjamarpu LF has been in doubt, having variously been determined to be Late Oligocene, Early Miocene and Middle Miocene in age (Archer, 1984; see Discussion).

Etymology. The species name alludes to the geographically extensive distribution of this species within Australia. Notios is Greek for 'southern' and planetes is Greek for 'wanderer'.

Descriptive diagnosis. This species differs from all other phalangeridan marsupials in the following combination of features: procumbent, lanceolate $\mathrm{I}_{1}$; obliquely orientated $\mathrm{P}_{1-2} ; \mathrm{P}_{2}$ crown is domeshaped and barely a fifth the height of $\mathrm{P}_{3} ; \mathrm{P}_{3}$ has (in transverse section) a teardrop-shaped crown with the apex much narrower than the base; $\mathrm{P}_{3}$ has two apical cuspules; buccal and lingual vertical struts/buttresses descend the flanks of the crown beneath both of the cuspules; anterior and posterior blades descend the anterior and posterior flanks of the two apical cuspules as parts of a continuous acute blade that extends the length of the $\mathrm{P}_{3} ; \mathrm{P}_{3}$ is pear-shaped in occlusal view but with buccal and more conspicuous lingual indentations of the crown margin half way along the crown 


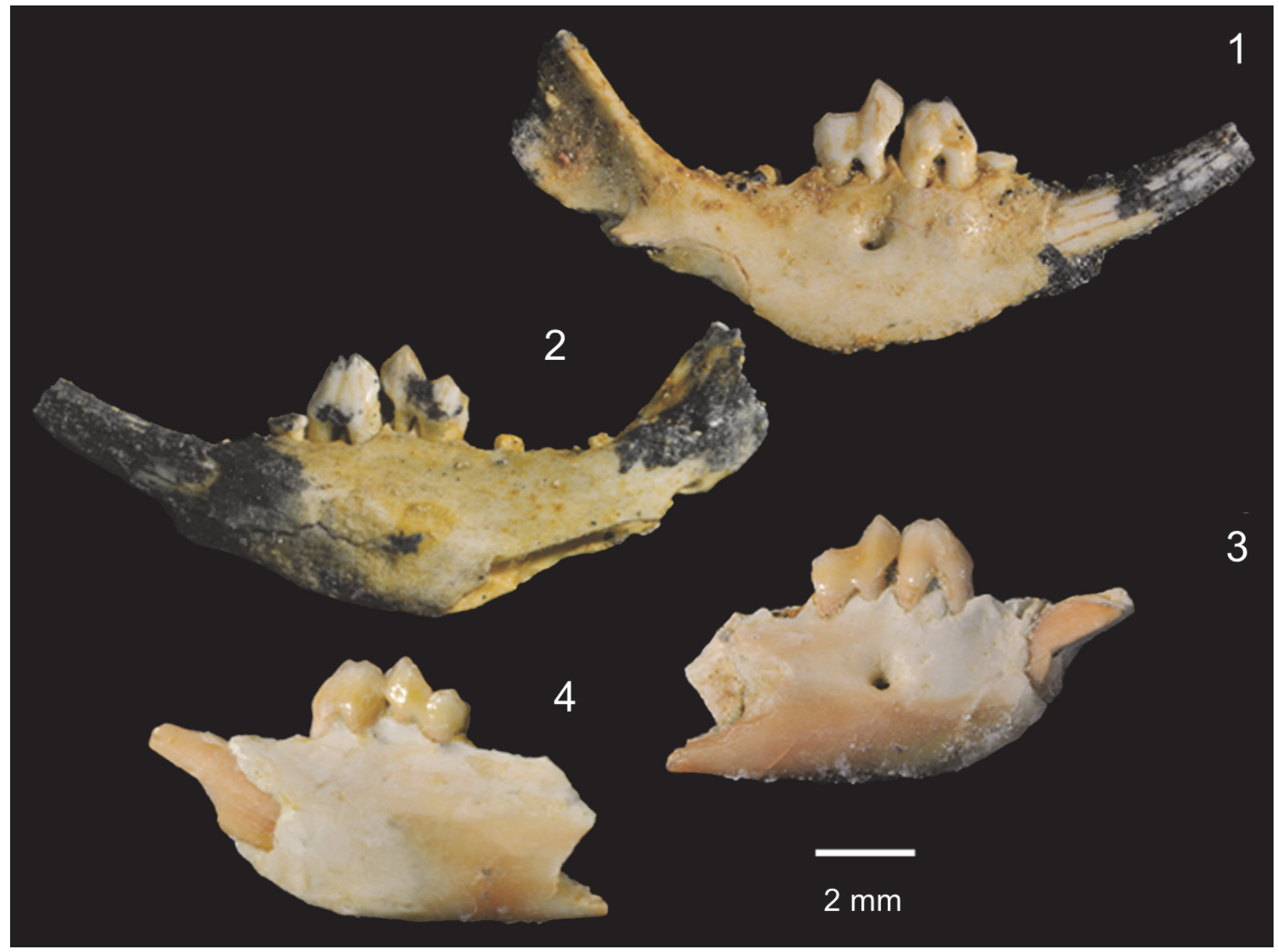

FIGURE 2. Miminipossum notioplanetes. 1-2, Holotype QM F57950, right dentary fragment with $I_{1}, P_{2-3}$ and $M_{1}$ buccal and lingual views respectively. 3-4, Referred specimen SAM P49184 (image reversed to facilitate comparison), left dentary fragment with $P_{3}, M_{1}$, and base of $I_{1}$, buccal and lingual views, respectively.

length resulting in an asymmetrical figure-eight basal crown outline; the trigonid of $M_{1}$ is twice the height of the talonid; the trigonid supports a high, obliquely-orientated blade that extends the function of the posterior end of the $\mathrm{P}_{3}$ blade; there are three prominent steeply-inclined blades/struts descending from the apex of protoconid thereby defining steeply inclined posterior, anterobuccal and anterolingual faces of the trigonid; the talonid supports a very large entoconid and comparably large hypoconid; there is no hypoconulid; the cristid obliqua intersects the posterior flank of the trigonid in a position well buccal to the midline of the tooth; the occlusal surface of the back of the trigonid and whole of the talonid basin is crenulated; a continuous blade surrounds the whole of the talonid basin; there is a carnassial notch at the junction of the posterior blade of the trigonid and anterior blade from the entoconid.
Description. Measurements are presented in Table 1. Morphological features of note in addition to those listed above as part of diagnoses include the following. The dentary is short, deep and robust compared with the dentaries of some phalangeridans such as acrobatids and burramyids. The symphysis extends posteriorly to a point below the trigonid of $M_{1}$. The mental foramen occurs below the trigonid of $M_{1}$.

In so far as the referred specimen from the Leaf Locality of central Australia can be compared with the holotype from Riversleigh (which primarily involves features of $I_{1}, P_{3}-M_{1}$ and alveoli for $P_{1-2}$ ), it is specifically indistinguishable. However, there are some minor differences that should be noted, although these may in part be the result of the more extensive wear sustained by the referred specimen in contrast to the almost unworn condition of the juvenile. The $P_{3}$ crown and $M_{1}$ trigonid 


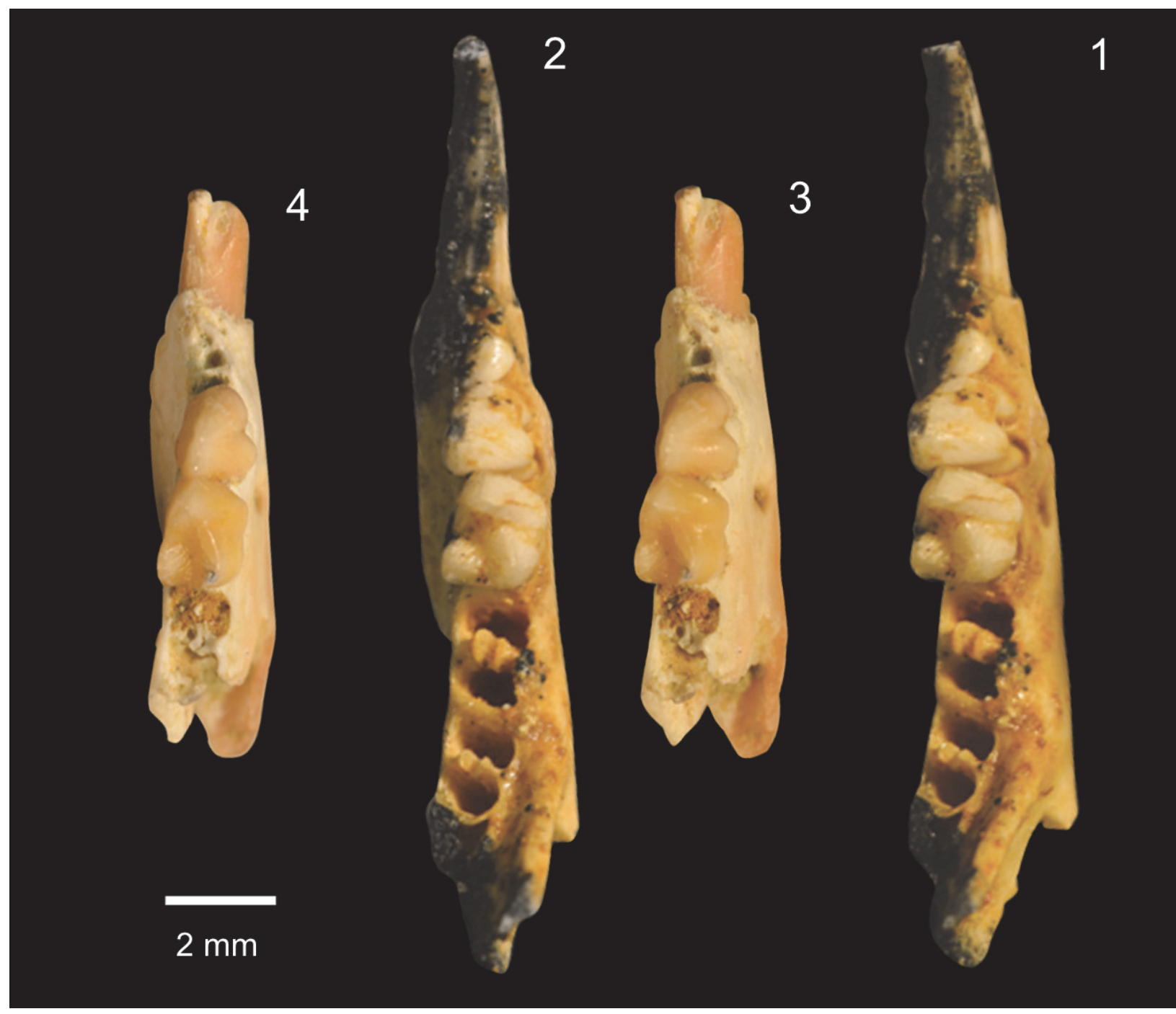

FIGURE 3. 1-2, stereophotographs of the holotype right dentary of Miminipossum notioplanetes (QM F57950). Teeth present are $I_{1}, P_{2}, P_{3}, M_{1}$. 3-4, stereophotographs of the referred partial left dentary SAM P49184 (image reversed to facilitate comparison). Teeth present are the base of $I_{1}, P_{3}, M_{1}$.

of the holotype appear to be slightly higher than that of the referred specimen. The longitudinal blade of $\mathrm{P}_{3}$ appears to descend more abruptly in the holotype. In the referred specimen, this posterior section of the longitudinal blade initially only gently slopes in a downward direction before plunging towards the base of the crown. Because both of these minor differences could be the result of differential wear in the two specimens, they are not regarded here to merit specific distinction. Hence, pending discovery of more complete specimens from the Leaf Locality, there is no clear reason for separating this population at the specific level from Miminipossum notioplanetes.
Remarks. There are upper molars, mostly isolated, from both the Leaf Locality and some of the sites at Riversleigh that may belong to this taxon. However, in the absence of undoubted association and the presence of many other groups of equally littleunderstood phalangeridan taxa in these sites, it seems prudent not to speculate about possible conspecific identity of upper teeth until more complete material is known.

\section{DISCUSSION}

Geochronology. The age of the Kutjamarpu LF in South Australia has been controversial. Stirton, Tedford and Woodburne (1968) speculated, on the basis of 'stage of evolution', that it was Middle Mio- 
TABLE 1. Comparative measurements (in mm) of Miminipossum notioplanetes sp. nov. specimens from the Two Trees (Queensland) and Kutjamarpu (South Australia) Local Faunas.

\begin{tabular}{lccc}
\hline & Length $\mathbf{M}_{\mathbf{1}}$ & Maximum width $\mathbf{M}_{\mathbf{1}}$ & Maximum height $\mathbf{M}_{\mathbf{1}}$ \\
\hline QM F57950 & 1.95 & 1.47 & 1.97 \\
SAM P49184 & 1.94 & 1.45 & 1.85 \\
& Length $\mathrm{P}_{\mathbf{3}}$ & Maximum width $\mathrm{P}_{\mathbf{3}}$ & Dent. depth below $\mathbf{M}_{\mathbf{1}}$ \\
QM 57590 & 1.63 & 1.42 & 3.95 \\
SAM P49184 & 1.55 & 1.44 & 4.10 \\
& Length $\mathrm{P}_{2}$ & Maximum width $\mathrm{P}_{2}$ & \\
QM 57590 & 1.01 & 0.81 & \\
\hline
\end{tabular}

TABLE 2. Mammal species shared between the Kutjamarpu Local Fauna of central Australia and faunal assemblages in Riversleigh Faunal Zones. Faunal Zone A (FZ A) = Late Oligocene. Faunal Zone B $(F Z$ B) = Early Miocene. Faunal Zone C $(F Z C)=$ Middle Miocene. Faunal Zone D (FZ D = late Middle or early Late Miocene.

\begin{tabular}{lrrrr}
\hline \multicolumn{1}{c}{ Taxon } & FZ A & FZ B & FZ C & FZ D \\
\hline Litokoala kutjamarpensis & - & + & + & - \\
Neohelos tirarensis & + & + & + & - \\
Wakaleo oldfieldi & - & + & + & - \\
Rhizophascolonus crowcrofti & + & + & + & - \\
Paljara tirarensae & - & + & + & + \\
Marlu kutjamarpensis & - & - & + & - \\
Marlu syke & - & + & + & - \\
Marlu ampelos & - & - & + & - \\
Ektopodon serratus & - & + & - & - \\
Wakiewakie lawsoni & - & + & - & - \\
Ganawamaya acris & - & + & + & - \\
Ganguroo bilamina & - & + & - & - \\
Madju variae & + & + & + & - \\
Bulungu palara & + & + & + & - \\
Miminipossum notioplanetes & - & - & + & - \\
\hline
\end{tabular}

cene in age. Woodburne et al. (1994) concluded that it was Late Oligocene in age. Archer et al. (1997), Travouillon et al. (2006) and Black et al. (2012, 2013) concluded that it was either Early or Middle Miocene based on comparisons with faunal assemblages of these two ages at Riversleigh.

Of the 15 small to large mammal taxa shared between the Kutjamarpu LF and the faunal assemblages at Riversleigh (Table 2; based on data in Black et al., 2012; Travouillon et al., 2006, 2013; Arena et al., 2015), the majority (12) of Kutjamarpu taxa are shared with Riversleigh taxa in Faunal Zones B (Early Miocene) and C (Middle Miocene). None are uniquely shared with Faunal Zones A (Late Oligocene) or D (early Late Miocene), but three are uniquely shared with Faunal Zone B sites and three with Faunal Zone C sites. Hence there are similar levels of support for concluding that the
Kutjamarpu Local Fauna is either Early or Middle Miocene based on biocorrelation. It is also possible that the Kutjamarpu LF is a Middle Miocene assemblage that happens to retain three long-surviving taxa otherwise only known from the Early Miocene assemblages of Riversleigh. Because mammal species survive for anywhere between 116 million years depending on a range of factors (Liow et al., 2008), based on biocorrelation alone, doubt remains about the precise age of the Kutjamarpu LF.

Until 2014, estimates of the ages of these Riversleigh assemblages were also based on biocorrelation. Uranium/lead dates for Faunal Zone C assemblages published by Woodhead et al. (2014) have since confirmed the Middle Miocene age estimate for these assemblages. The Two Trees LF from Riversleigh was originally estimated by Flan- 
nery and Archer (1987) to be Middle Miocene in age on the basis of biostratigraphy. The geostratigraphic position of the Two Trees Site at Riversleigh strongly suggests that the Two Trees LF is, like all others with which it is geographically associated, Middle Miocene in age (Creaser, 1997; Arena, 2014, 2015). It occurs in the freshwater limestone deposits exposed at the northeastern end of the Gag Plateau where speleothems from adjacent sites (e.g., Ringtail Site and D4 Site; Woodhead et al., 2014) have been radiometrically dated (see above) as Middle Miocene.

Palaeoenvironment. While there have been many palaeoenvironmental interpretations of the Riversleigh faunal assemblages (e.g., Bassarova, 2005; Travouillon et al., 2009), this is not the case for the Kutjamarpu LF for which there is very little speculation about palaeoenvironments other than that trees and water must have been present (Campbell, 1976). Fossil plants from the overlying Leaf Shale of the Wipajiri Fm have not yet been the subject of systematic taxonomic or palaeoenvironmental assessment. Given the continentally central position of the Leaf Locality (now part of the Tirari Desert in northern South Australia), it would not be particularly surprising if this land-locked area had a different Early/Middle Miocene palaeoenvironment than that which characterized Riversleigh's relatively peripheral position near the northern edge of the continent. However, at least 15 marsupial species were shared between the Early and Middle Miocene communities of Riversleigh and the Kutjamarpu LF, which is far more shared marsupial species than occurs in any non-identical habitats in Australia today. Accordingly, it would seem justifiable to at least hypothesize that the temperate wet forest palaeoenvironments interpreted to characterize Riversleigh during the Early and Middle Miocene (e.g., Travouillon et al., 2009) may well have extended into central Australia. Alternatively, it is also possible that what may have been a regionally widespread ecosystem of this kind in northern Australia was represented in central Australia by only a lush riparian palaeoenvironment with a different, as yet unknown, possibly drier palaeoenvironment marginal to the westward flowing river system that produced the Wipajiri Formation. The fact that the Kutjamarpu and Riversleigh assemblages are not identical (e.g., there are a few non-shared conge- neric species unique to both areas such as two different species of Barinya; Binfield et al., 2016) may be seen as support for a regional difference of this kind.

Biodiversity. Recognition of Miminipossum as yet another phalangeridan lineage has significantly expanded the morphological breadth of this group. Miminipossum is similar to petaurids based on some features such as dentary form, posteriorlyreducing molar size, small size of $P_{1}$, longitudinal serrated blade on $P_{3}$, three-bladed stout trigonid on $M_{1}$, low crenulated talonid basins and large entoconids. However, these are all features that appear to be homoplasious among a range of phalangeridan groups including some phalangerids, pilkipildrids and burramyids. For this reason, given the relatively limited morphological features known for this new lineage and widespread convergence in the morphology of both $\mathrm{P}_{3}$ and $\mathrm{M}_{1}$ in many phalangeridan groups, a detailed phylogenetic analysis would be premature and possibly misleading at this stage. For similar reasons Brammall (1998) concluded that the relationships of Djaludjangi with or within Petauridae were ambiguous. However, given that the distinctive features of Miminipossum notioplanetes set it as far apart from existing phalangeridan families as those families are from each other, we do not hesitate to distinguish this newly recognised group at the family level.

\section{ACKNOWLEDGEMENTS}

Support for our research has come from the Australian Research Council (LP100200486, DP1094569, DP130100197, DE130100467 and DP170101420 grants to M. Archer, S. J. Hand and K. H. Black); the University of New South Wales; P. Creaser and the CREATE Fund; the Queensland Parks and Wildlife Service; Environment Australia; the Queensland Museum; the Riversleigh Society Inc.; Outback at Isa; Mount Isa City Council; the Waanyi people of northwestern Queensland; and private supporters including K. and M. Pettit, E. Clark, M. Beavis, M. Dickson and the Rackham family including Alan Snr, Alan Jnr, Kerry and Dale. Assistance in the field has come from many hundreds of volunteers as well as staff and postgraduate students of the University of New South Wales and the South Australian Museum. 


\section{REFERENCES}

Aplin, K., and Archer, M. 1987. Recent advances in marsupial systematics with a new syncretic classification, p. xv-Ixxii. In Archer, M. (ed.), Possums and Opossums: Studies in Evolution. Surrey Beatty and Sons Pty Ltd and the Royal Zoological Society of New South Wales, Sydney.

Archer, M. 1984. The Australian marsupial radiation, p. 633-808. In Archer, M. and Clayton, G. (eds.), Vertebrate Zoogeography \& Evolution in Australasia. Hesperian Press, Perth.

Archer, M., Arena, R., Bassarova, M., Black, K., Brammall, J., Cooke, B.N., Crosby, K., Godthelp, H., Gott, M., Hand, S.J., Kear, B., Krikmann, A., Mackness, B., Muirhead, J., Musser, A., Myers, T.J., Pledge, N., Wang, Y., and Wroe, S. 1999. The evolutionary history and diversity of Australia's mammals. Australian Mammalogy, 21:1-45.

Archer, M. and Hand, S.J. 1984. Background to the search for Australia's oldest mammals, p. 517-565. In Archer, M. and Clayton, G. (eds.), Vertebrate Zoogeography \& Evolution in Australasia. Hesperian Press, Perth.

Archer, M., Hand, S.J., and Godthelp, H. 1995. Tertiary environmental and biotic change in Australia, p. 77-90. In Vrba, E., Denton, G.H., Partridge, T.C., and Burckle, L.H. (eds.), Paleoclimate and Evolution, with Emphasis on Human Origins. Yale University Press, New Haven.

Archer, M., Hand, S.J., and Godhelp, H. 1997. Australia's Lost Worlds. Indiana Press, USA.

Archer, M., Hand, S.J., Godthelp, H., and Creaser, P. 1997. Correlation of the Cainozoic sediments of the Riversleigh World Heritage fossil property, Queensland, Australia, p. 131152. In Aguilar, J.P., Legendre, S., and Michaux, J. (eds.), Actes du Congrès BiochroM'97. École Pratique des Hautes Études Institut de Montpellier, France.

Arena, D.A. 2004. The Geological history and development of the terrain at the Riversleigh World Heritage Area during the Middle Tertiary. Unpublished PhD Thesis, University of New South Wales, Sydney, Australia.

Arena, D.A., Black, K.H., Archer, M., Hand, S.J., Godthelp, H., and Creaser, P. 2014. Reconstructing a Miocene pitfall trap: recognition and interpretation of fossiliferous Cenozoic palaeokarst. Sedimentary Geology 304:28-43. http://doi.org/10.1016/j.sedgeo.2014.01.005.

Arena, D.A., Travouillon, K.J., Beck, R.M.D., Black, K.H., Gillespie, A.K., Myers, T.J., Archer, M., and Hand, S.J. 2015. Mammalian lineages and the biostratigraphy and biochronology of Cenozoic faunas from the Riversleigh World Heritage Area, Australia. Lethaia, 49:43-60. http://doi:10.1111/let.12131

Binfield, P., Archer, M., Hand, S.J., Black, K.H., Myers, T.J., Gillespie, A.K., and Arena, D.A. 2016. A new carnivorous marsupial, Barinya kutjamarpensis (Dasyuromorphia), from central Australia. A/cheringa http://doi:10.1080/03115518.2016.1180029.

Bassarova, M. 2005. Taphonomic and palaeoecological investigations of Riversleigh OligoMiocene fossil sites. Unpublished PhD Thesis, University of New South Wales, Sydney, Australia.

Bassarova, M., Archer, M., and Hand, S.J. 2001. New species of ringtail possums (Pseudocheiridae, Marsupialia) referable to the Oligo-Miocene genus Paljara from deposits of the Riversleigh World Heritage property, northwestern Queensland. Memoirs of the Association of Australasian Palaeontologists, 25:61-75.

Black, K. 1997. Diversity and biostratigraphy of the Diprotodontoidea of Riversleigh, northwestern Queensland. Memoirs of the Queensland Museum, 41:187-192.

Black K.H., Archer, M., Hand, S.J., and Godthelp H. 2012. The rise of Australian marsupials: a synopsis of biostratigraphic, phylogenetic, palaeoecologic and palaeobiogeographic understanding, p. 983-1078. In Talent, J.A. (ed.), Earth and Life: Global Biodiversity, Extinction Intervals and Biogeographic Perturbations Through Time. International Year of Planet Earth Series, Springer Verlag, Dordrecht.

Black, K.H., Archer, M., Hand, S.J., and Godthelp, H. 2013. Revision in the diprotodontid marsupial genus Neohelos. Systematics and biostratigraphy. Acta Palaeontologica Polonica, 58:679-706.

Black, K.H., Louys, J., and Price, G.J. 2014a. Understanding morphological variation in the extant koala as a framework for identification of species boundaries in extinct koalas (Phascolarctidae; Marsupialia), Journal of Systematic Palaeontology, 12:237-264.

Black, K.H., Price, G., Archer, M., and Hand, S.J. 2014. Bearing up well? Understanding the past, present and future of koalas. Gondwana Research, 25:1186-1201. 
Brammall, J.R. 1998. A new petauroid possum from the Oligo-Miocene of Riversleigh, northwestern Queensland. Alcheringa, 23:31-50.

Brammall, J.R. and Archer, M. 1999. Living and extinct petaurids, acrobatids, tarsipedids and burramyids (Marsupialia): relationships and diversity through time. Australian Mammalogy, 21:24-25.

Brewer, P. Archer, M., and Hand, S.J. 2008. Additional specimens of the oldest wombat Rhizophascolonus crowcrofti (Vombatidae; Marsupialia) from the Wipajiri Formation, South Australia: an intermediate morphology? Journal of Vertebrate Paleontology, 28:1144-1148.

Campbell, C. 1976. Tertiary Dasyuridae and Peramelidae (Marsupialia) from the Tirari Desert, South Australia. Unpublished PhD Thesis, University of California, Berkeley, USA.

Cooke, B.N., Travouillon, T.J., Archer, M., and Hand, S.J. 2015. Ganguroo robustiter, sp. nov. (Macropodoidea, Marsupialia), a middle to early late Miocene basal macropodid from Riversleigh World Heritage Area, Australia, Journal of Vertebrate Paleontology. https:// doi.org/10.1080/02724634.2015.956879.

Creaser, P. 1997. Oligocene-Miocene sediments of Riversleigh: the potential significance of topography. Memoirs of the Queensland Museum, 41:303-314.

Flannery, T.F. and Archer, M. 1987. Bettongia moyesi, a new and plesiomorphic kangaroo (Marsupialia: Potoroidae) from Miocene sediments of northwestern Queensland, p. 759-767. In Archer, M. (ed.), Possums and Opossums: Studies in Evolution. Surrey Beatty and Sons Publishing and The Royal Zoological Society of New South Wales, Sydney.

Gillespie, A.K., Archer, M., Hand, S.J., and Black, K.H. 2014. New material referable to Wakaleo (Marsupialia: Thylacoleonidae) from the Riversleigh World Heritage Area, northwestern Queensland: revising species boundaries and distributions in Oligo-Miocene marsupial lions. Alcheringa, 38:513-527.

Godthelp, H., Archer, M., Hand, S.J., and Plane, M.D. 1989. New potoroine from Tertiary Kangaroo Well Local Fauna, Northern Territory and description of upper dentition of potoroine Wakiewakie lawsoni from Upper Site Local Fauna, Riversleigh, p. 6. In 5th Conference on Australian Vertebrate Evolution, Palaeontology and Systematics Abstracts, The National Science and Technology Centre, Canberra, 18-20 April 1995.

Liow, L.H., Fortelius, M., Bingham, E., Lintulaakso, K. Manila, H., Flynn, L., and Stenseth, N.C. 2008. Higher origination and extinction rates in larger mammals. Proceedings of the National Academy of Sciences, 105:6097-6102.

Owen, R. 1866. On the Anatomy of Vertebrates. Volume 11. Longmans, Green, London.

Pledge, N.S., Archer, M., Hand, S., and Godthelp, H. 1999. Additions to knowledge about ektopodontids (Marsupialia: Ektopodontidae): including a new species Ektopodon litolophus. Records of the Western Australian Museum Supplement, 57:255-264.

Roberts, K.K., Archer, M., Godthelp, H., and Hand, S.J. 2009. New Oligo-Miocene species of Marlu (Pseudocheiridae, Marsupialia) with a revision of the genus. Palaeontology, 52:441456.

Roberts, K.K., Bassarova, M., and Archer, M. 2008. Oligo-Miocene ringtail possums of the genus Paljara (Pseudocheiridae: Marsupialia) from Queensland, Australia. Geobios, 41:441-56.

Stirton, R.A., Tedford, R.H., and Woodburne, M.O. 1967. A new Tertiary formation and fauna from the Tirari Desert, South Australia. Records of the the South Australian Museum, 15:428462.

Stirton, R.A., Tedford, R.H., and Woodburne, M.O. 1968. Australian Tertiary deposits containing terrestrial mammals. University of California Publications in Geological Sciences, 77:1-30.

Travouillon, K.J., Archer, M., Hand, S.J., and Godthelp, H. 2006. Multivariate analyses of Cenozoic mammalian faunas from Riversleigh, northwestern Queensland. Alcheringa Special Issue, 1:323-349.

Travouillon, K.J., Beck, R.M.D., Hand, S.J., and Archer, M. 2013. The oldest fossil record of bandicoots (Marsupialia; Peramelemorphia) from the late Oligocene of Australia. Palaeontologia Electronica 16.2.13A: 1-52 palaeo-electronica.org/content/2013/400-lateoligocene-bandicoot

Travouillon, K.J., Cooke, B.N., Archer, M., and Hand, S.J. 2014. Revision of basal macropodids from the Riversleigh World Heritage Area with descriptions of new material of Ganguroo bilamina Cooke, 1997 and a new species. Palaeontologia Electronica. Article number: 17.1.20A: 1-34. palaeo-electronica.org/content/2014/711-riversleigh-basal-macropodoids 
Travouillon, K.J., Legendre, S., Archer, M., and Hand, S.J. 2009. Palaeoecological analyses of Riversleigh's Oligo-Miocene deposits: implications for Oligo-Miocene climate change in Australia. Palaeogeography, Palaeoclimatology, Palaeoecology, 276:24-37.

Woodburne, M.O., MacFadden, B.J., Case, J.A., Springer, M.S., Pledge, N.S., Power, J.D., Woodburne, J.M., and Springer, K.B. 1994. Land mammal biostratigraphy and magnetostratigraphy of the Etadunna Formation (late Miocene) of South Australia. Journal of Vertebrate Paleontology, 13:483-515.

Woodburne, M.O. and Tedford, R.H. 1975. The first Tertiary monotreme from Australia. American Museum Novitates, 2588:1-11.

Woodhead, J., Hand, S.J., Archer, M., Graham, I., Sniderman, K., Arena, D.A., Black, K.H., Godthelp, H., Creaser, P., and Price, E. 2014. Developing a radiometrically-dated chronologic sequence for Neogene biotic change in Australia, from the Riversleigh World Heritage Area of Queensland. Gondwana Research, http://doi:10.1016/j.gr.2014.10.004. 